\title{
DOES THE EFFECT OF PUBLIC SUPPORT FOR R\&D DEPEND ON THE DEGREE OF APPROPRIABILITY?*
}

\author{
Liliana Gelabert ${ }^{\dagger}$ \\ ANDREA FOSFURI ${ }^{\ddagger}$ \\ JoSEPA. TRIBó ${ }^{\S}$
}

\begin{abstract}
We explore the interaction between public support for R\&D and appropriability using a dataset constructed from the Spanish Community Innovation Survey, for the period 2000-2005. We find that public support policy is less able to stimulate privately financed internal $R \& D$ in firms where appropriability mechanisms are more effective. On average, the effect of public support for R\&D is three times larger for those firms reporting a level of appropriability below the median visà-vis those firms for which appropriability is above the median level. Furthermore, for supported firms with the highest degree of appropriability, crowding out cannot be ruled out.
\end{abstract}

\section{INTRODUCTION}

INNOVATION POLICY IS ONE OF THE MAJOR CHALLENGES for policy makers in developed countries. Public intervention in R\&D activities is justified by the imperfect appropriability that applies to knowledge production (Arrow [1962], Nelson [1959]). The implication of this market failure is that firms underinvest in R\&D activities since they cannot fully appropriate the social returns stemming from their innovations. In this context, governments have

\footnotetext{
${ }^{*}$ We gratefully acknowledge financial support from the Fundación Ramón Areces and research assistance from the Spanish National Institute of Statistics (INE). We would like to thank C. Alonso, A. Arora, M. Bagüés, R. Carrasco, W. Cohen, M. Giarratana, R. Fontana, J. Jaumandreu, P. Ruiz-Verdú, O. Toivanen, F. Warsynski, the Editor, an anonymous referee, and seminar participants at the Universidad Carlos III de Madrid, Universidad Internacional Menendez Pelayo (Escuela de Economía de la Innovación Zvi Griliches), Universitat Autònoma de Barcelona, Universidad de Vigo, 2006 EURAM Conference (Oslo), 2006 DRUID Summer Conference (Copenhagen), 2006 EARIE Conference (Amsterdam), and 2006 Jornadas de Economía Industrial (Barcelona), for comments and suggestions on a previous draft. The usual disclaimer applies.

†Authors’ affiliations: IE University, Campus de Santa Cruz la Real, Cardenal Zúñiga 12, Segovia (4003), Spain. e-mail: liliana.gelabert@ie.edu

${ }^{\ddagger}$ Department of Business Administration, Universidad Carlos III de Madrid, Calle Madrid, 126, Getafe, (28903). Spain. e-mail: andrea.fosfuri@uc3m.es

${ }^{\S}$ Department of Business Administration, Universidad Carlos III de Madrid, Calle Madrid, 126, Getafe, (28903). Spain.

e-mail: joatribo@emp.uc3m.es
} 
three potential mechanisms to alleviate such market failure: first, by undertaking public R\&D activities through research institutes or national laboratories or contracting out $\mathrm{R} \& \mathrm{D}$ activities to private firms in those areas where appropriability problems are acute; second, by strengthening the protection for intellectual property rights (IPR), thereby increasing the share of social returns that the innovator can ultimately appropriate; finally, by implementing incentive mechanisms like tax benefits, subsidies or public loans at low/null interest rates, which, in turn, would reduce $R \& D$ costs for private firms. ${ }^{1}$

In this paper we deal with the latter mechanism, namely, public support for R\&D. The dominant theme of the literature on public support policies is related to their net effect on firm R\&D investment, that is, assessing empirically the extent to which public support induces or substitutes privately financed R\&D expenses (see Hall and Van Reenen [2000], Klette et al. [2000], David et al. [2000] for surveys of the existing literature). We offer a new twist to this literature by focusing on the contingencies that moderate the effect of R\&D support policies, rather than by just measuring their impact on privately financed R\&D spending. Put differently, our objective here is to explain the heterogeneity across firms in the effect of R\&D support policies. Specifically, we focus on the role played by the degree of appropriability, i.e., the ability to appropriate the rents associated with an innovation. Although the concept of appropriability is central to the theoretical argument that justifies public intervention in $R \& D$ activities (Arrow [1962]), to the best of our knowledge, there is no attempt in the literature to incorporate appropriability issues when assessing the effect of R\&D support policies empirically.

Drawing on data from the Spanish Community Innovation Survey (CIS), for the period 2000-2005, we find that the elasticity of privately financed R\&D expenditures with respect to public support decreases with the degree of appropriability. That is, firms that have reported that mechanisms to protect innovation are more effective respond with a smaller increase in privately financed $R \& D$ when they receive public support. Moreover, when protection mechanisms are identified as being extremely effective, we cannot rule out the existence of crowding out, i.e., the amount of investment in $\mathrm{R} \& \mathrm{D}$, net of the government support, shrinks. This finding is robust to several controls for the endogeneity of public support, and for unobserved heterogeneity across firms. It is also robust to the inclusion of other determinants of the effectiveness of public support discussed in the literature such as, for instance, firm size and financial constraints (Hyytinen and Toivanen [2005], González and Pazó [2008]), and across different empirical models (2SLS, Tobit, matching approach). Although, theoretically, there are several explanations as to why this could happen, an intuitive

\footnotetext{
${ }^{1}$ Both IPR protection and public support policies are formulated to have a direct effect on private incentives to innovate by enhancing profitability and reducing R\&D costs, respectively.
} 
interpretation is that firms with stronger appropriability are more likely to ask for public support purely as a way of reducing the cost of projects that were profitable in the first place without such support; whereas those firms that face appropriability problems are more likely to ask for public support in order to make an $\mathrm{R} \& \mathrm{D}$ project profitable.

The rest of the article is structured as follows. Section II summarizes the existing literature on public support for R\&D activities, motivates our study and explains its contribution. Section III describes the data and variables used in the empirical analysis. In section IV we discuss the endogeneity bias affecting public support, present our instrument, and report the results of the baseline empirical model, namely, a two-stage least squares estimation with firm fixed effects. Section V presents several robustness checks that further corroborate our main finding. The paper concludes with some final remarks.

\section{RELATED LITERATURE AND CONTRIBUTION}

The extensive literature reviewed by Jaffe [1996] documents the presence of spillovers in $R \& D$ activities. A crucial consequence of these spillovers is that the value generated by innovation may be captured by: competitors, owners of complementary assets, consumers, etc. (Teece, [1986]). Hence, as a result, firms would tend to invest below the socially optimal level of R\&D (Griliches [1992]). Does public support for R\&D activities solve this market failure? A necessary condition for an affirmative answer is that privately financed R\&D expenditures increase after a firm receives public support. This occurs because public support can reduce both the fixed and the marginal cost of R\&D activity. Lach [2002] suggests that the likelihood of stimulating further private $R \& D$ expenditures is higher when the subsidized project involves setting-up or upgrading research facilities that have the potential to lower the fixed costs of other current, or future, non-subsidized R\&D projects. In addition to the direct effect, public support for R\&D might also have an indirect effect that lowers further the marginal cost of $R \& D$ activities. Lerner [1999] and Hall [2002], among others, argue that public support could represent a positive endorsement of the quality of a firm's R\&D activity in the eyes of potential investors which, in turn, reduces their required return when providing additional funds. For instance, Lerner [1999] mentions, as an example, that specialists at the National Institutes of Health or at the Department of Defense may have considerable insight about which biotechnology or advanced materials companies are the most promising. $^{2}$

\footnotetext{
${ }^{2}$ To test for the existence of this effect, Lerner examines the performance of high-technology firms that receive funds from a major public venture initiative, and compares it with a sample of matching firms. He finds that while awardees and matching firms did not differ significantly in the likelihood of receiving private venture capital in the years prior to the award, in subsequent
} 
Although the ultimate aim of public support is to stimulate further company funded $R \& D$ expenditures, one cannot discard the possibility that public grants substitute for private money, the so-called crowding out effect. This could be the case when public agencies fund projects with higher success probabilities to avoid appearing to squander public money (Lach, [2002], Wallsten [2000]). In this situation, the firm does not decide to invest additional money in the subsidized project as a consequence of receiving the grant. ${ }^{3}$ Moreover, David et al. [2000] argue that, even if the grant attracts additional private money into the subsidized project, the overall effect on privately financed $R \& D$ expenditures can still be negative because the private money flowing to the subsidized project may come from other nonsubsidized ones. In particular, they claim that an inelastic supply of R\&D inputs which drives prices up, together with liquidity constraints, reduce the cost effectiveness of investing in non-subsidized projects. As a result, a firm may decide to discontinue an active $\mathrm{R} \& \mathrm{D}$ project in order to allocate those resources to the subsidized one. In this situation, the amount of privately financed $R \& D$ expenditures may increase, or decrease, depending on the relative importance of each project.

The existing evidence about the effectiveness of $\mathrm{R} \& \mathrm{D}$ public support policies is rather mixed. David et al. [2000] systematically survey the econometric work over the last 35 years and suggest that conflicting results arise from: different levels of aggregation; the multiplicity of econometric techniques; the existence of different national support programs and a lack of a formal framework. Most importantly, most of the older studies do not properly take into account the potential endogeneity of public support, i.e., public support is not randomly allocated across firms.

More recent studies on the evaluation of $R \& D$ policies, all of which control for endogeneity, still provide conflicting results. For instance, Wallsten [2000] finds that grants provided by the Small Business and Innovation Program (a U.S. program directed at providing grants to small firms), crowd out privately financed R\&D, dollar for dollar. On the contrary, Lach [2002] shows that subsidies induce 11 additional monetary units of in-house R\&D for each unit of subsidy received by small Israeli firms, while the effect is negative, albeit insignificantly, for large Israeli firms. Czarnitzki and Licht [2006] find a large degree of additionality in public $R \& D$ grants in relation to privately financed $R \& D$ expenses in Germany, with a more pronounced effect in Eastern Germany during the transition

years, the awardees were significantly more likely to receive such financing. This finding is consistent with the receipt of awards playing an important role in certifying firm quality.

${ }^{3}$ However, even when crowding out occurs on the subsidized project, the overall effect on a firm's privately financed R\&D expenditures depends on the final assignation of the funds released by the subsidy. If the firm is liquidity constrained, it could decide to undertake another project that could not have otherwise been financed; thus, counterbalancing the substitution effect on the subsidized project. 
period. Busom [2000] analyses the effect of Spanish government subsidies on R\&D using a sample of 147 firms, and finds that for $30 \%$ of the firms, full crowding out cannot be ruled out. More recently, González et al. [2005] address the same issue using a panel of about 2,000 firms. The econometric analysis controls for the censoring of the $R \& D$ variable and for the potential endogeneity of public grants. They find that public subsidies play a positive, although modest, role. The estimated percentage increase in privately financed $R \& D$ expenditures is higher for the smallest firms. These firms are also more likely to start R\&D activities after receiving a subsidy. However, the analysis also suggests that subsidies go mainly to firms that would have performed innovative activities irrespective of such subsidies.

Such conflicting findings may suggest that the effect of public support for stimulating $R \& D$ activities is contingent on firm characteristics and, thus, heterogeneous across recipient firms. A few studies have focused on the moderating role of firm size. Specifically, Lach [2002], González et al. [2005] and González and Pazó [2008] provide evidence consistent with the notion that smaller firms are more likely to increase their privately financed $R \& D$ expenditures as a consequence of public support. A conjectured explanation for this finding is that smaller firms tend to suffer from financial constraints, which the public support might help to alleviate. In line with this conjecture, Hyytinen and Toivanen [2005], using survey data for Finland, show that government funding disproportionately helps firms from industries that are dependent on external financing.

We follow this line of research and, specifically, investigate the interaction between public support and appropriability on a firm's privately financed $\mathrm{R} \& \mathrm{D}$ expenditures. To the best of our knowledge this relationship has not yet been addressed in the existing literature on R\&D policies; neither from a theoretical nor empirical point of view. This is even more surprising if one takes into account the fact that governments can influence the degree of appropriability by, for instance, enforcing stricter IPR protection. Hence, appropriability and public support for $\mathrm{R} \& \mathrm{D}$ are two alternative channels to affect directly a firm's incentive to innovate. Showing that one policy is more or less effective when the other is also implemented actively is both interesting from an empirical standpoint and relevant in practice. Thus, our paper not only contributes to the existing literature by proposing a different lens through which the heterogeneity in the effect of R\&D subsidies can be analyzed, but it also sheds light on how different policy instruments that stimulate R\&D activities interact with each other.

\section{DATA AND VARIABLES}

\section{III (i). Sample}

The empirical analysis relies on data from the Community Innovation Survey (CIS) carried out in Spain between 2000 and 2005 by the National 
Institute of Statistics (INE). ${ }^{4}$ The sampling design of the CIS survey is as follows. All firms that have received any form of public support for R\&D or those that have reported R\&D expenses, in the last 20 years, are surveyed every year. The rest of the surveyed firms come from a random sample stratified by size and sector among non-R\&D performing firms. Given that Spanish firms have a legal obligation to respond to questionnaires submitted by the INE, the response rate is usually large (around 90\%). Firms that do not undertake any $\mathrm{R} \& \mathrm{D}$ activity during the period under study are excluded from the analysis. ${ }^{5}$ After removing firms with missing values and firms that did not report any positive internal R\&D expenditure during the whole period, we are left with an unbalanced panel of firms across a period of five years, comprising 5045 observations. ${ }^{6}$

\section{III (ii). Core Variables}

Private $R \& D$ In the survey, firms are asked to report their total expenditures in internal $R \& D$ activities. ${ }^{7}$ They also have to report the percentage breakdown of the different sources of funds: internal funds; other firms; public agencies; universities and non-profit institutions; EU programs or foreign funds. Internal funds, corresponding to privately financed internal $R \& D$ expenses, is the dependent variable in the empirical analysis (Private $R \& D$ ). Due to the skewness of the distribution, we use the logarithm of one plus the level of this variable in our estimations.

Public Support The level of public support is defined as the total amount of non-repayable public funds received by the firm, in order to finance internal $R \& D$ activities. It does not include public loans since loans must be reimbursed and are, therefore, classified as internal funds in the survey. Our independent variable measuring public support (Public Support) consists, therefore, of subsidies and public funds for $R \& D$ activities proceeding from contracts between the firm and public agencies. Due to the skewness of the distribution we use the logarithm of one plus the level of public support in

\footnotetext{
${ }^{4}$ We do not have the complete sample for the year 2001 so our panel includes the years 2000 , 2002, 2003, 2004 and 2005.

${ }^{5}$ The inclusion of these firms does not alter our main findings. See footnote 19 for more details.

${ }^{6}$ We checked that the records removed for missing values were not different from the sample we used finally. Specifically, for several observable dimensions, we could not reject the null hypotheses of equal means for the firms included in the sample and those left out. As a further robustness check, an earlier version of the paper used only a cross-section from the year 2002 (and lagged independent variables from the year 2000) to run our regressions. This sample included 1,265 firms and delivered qualitatively similar findings.

${ }^{7}$ Precisely, this is defined as "creative tasks developed inside the firm in a systematic way with the purpose of increasing the know-how to create new or improved applications as products (goods or services) or processes (including research in software).'
} 
our estimations. ${ }^{8}$ Given that subsidies and contracts are two different policy mechanisms, and exploiting the fact that the survey provides disaggregated information about the relative amount of subsidies and contracts for the years 2003 and 2005, we use that information to test the robustness of our results by focusing only on those sectors for which contracts are hardly used (see section $\mathrm{V}$ on extensions). ${ }^{9}$

Appropriability Only for the year 2000, the survey has a section with seven questions where firms are asked about the effectiveness of different appropriability mechanisms that are classified in two groups: 'written methods' (patents, models/designs, trademarks and copyrights) and 'strategic methods' (trade secret, design complexity and lead time). The answers are displayed on a Likert scale from 1 (important) to 4 (unimportant). These two kinds of appropriability mechanisms are known in the literature as legal and strategic appropriability mechanisms (see, for instance, Cassiman and Veugelers [2002]). We use the 2000 survey data to build a firm-level measure of appropriability (Appropriability); that is the sum of the scores for the four questions regarding legal protection mechanisms (patents, models/designs, trademarks and copyrights) and rescale it such that it varies between 0 (minimum level) and 1 (maximum level).

Concerning our measure of appropriability it is worthwhile to discuss the following issues. First, since we only have data on appropriability for the year 2000, our measure has no time variation. We therefore assume that appropriability depends essentially on characteristics that are constant over time, or at least during the period under analysis. Second, we restrict our measure to those questions related to legal appropriability mechanisms because we want to explore the interaction between public support and the effectiveness of IPR, which are policy mechanisms. Moreover, legal appropriability in Spain is unlikely to have varied substantially over the period under scrutiny. However, results (see section V(i) on extensions) do not change qualitatively, when we include questions related to strategic methods, in our measure of appropriability. Finally, some comments concerning the use of a firm level measure of appropriability. Cockburn and Griliches [1988] explore the ability of different appropriability measures, based on subjective assessments from the Yale Survey data (Levin et al. [1987]), to explain inter-industry differences. They find that measures based on all appropriability mechanisms (strategic and legal) were less effective as proxies for industry appropriability regimes than those based exclusively on

\footnotetext{
${ }^{8}$ In an earlier version of the paper, we have estimated our regressions in levels obtaining qualitatively similar results.

${ }^{9}$ David et al. [2000] discuss the potential differences between both kinds of R\&D policies when trying to measure the net effect on privately financed $R \& D$ expenses.
} 
legal mechanisms. Remarkably, they also find, as we do, more variation in legal appropriability at an intra-industry level rather than across industry averages. This large intra-industry variation could be due to differences in managers' opinions when responding to the survey as well as to perceived differences in the potential use that the same appropriability mechanism has for different firms. Although using managers' perceptions introduces some subjectivity in our measure of appropriability, those perceptions are key in driving firms' R\&D decisions. Thus, some measurement error notwithstanding, a firm-level measure of appropriability captures firm-level variations within sectors, and has more explanatory power than industry averages (Cassiman and Veugelers [2002]).

Given that the purpose of this paper is to capture the moderating role of appropriability on the relationship between public support for $R \& D$ activities and privately financed internal $R \& D$ expenses, we introduce an interaction term between our measures of public support and appropriability in all estimated specifications.

\section{III (iii). Control Variables}

We include several variables to control for other sources of heterogeneity across firms, with respect to their R\&D decisions.

Financial constraints are expected to affect the level of privately financed R\&D expenditures because firms facing financial constraints have a higher marginal cost of capital (Hall [2002], Hyytinen and Toivanen [2005]). In most studies, financial constraints have been proxied by firm size. Fortunately, the Spanish CIS survey allows us to build a quite precise measure of financial constraints. In fact, except for the year 2002, firms are asked to rate the importance of three financial factors that limit their ability to undertake R\&D activities. ${ }^{10}$ In order to obtain a firm-level measure of the strength of financial constraints for every year we add the scores of the three questions and rescale the total such that it varies between 0 and 1 , where 0 indicates that financial constraints are unimportant while 1 stands for the highest degree of importance. We define such a variable as Financial Constraints. For the year 2002, we assign the average level of the computed index for the years 2000 and 2003 . $^{11}$

Previous evidence suggests that public support is less effective for less financially constrained firms. For instance, Hyytinen and Toivanen [2005] demonstrate that government funding disproportionately helps firms from industries that are more dependent on external finance. It is, therefore, very

\footnotetext{
${ }^{10}$ The three factors that firms are asked to rate as potential impediments to innovation are: a) excessive economic risks; b) high innovation costs; c) lack of suitable external finance for innovation activity. Scores go from 1 (very important) to 4 (unimportant). Results do not change qualitatively if we use the answers to c) only.

${ }^{11}$ Results are not qualitatively affected if we simply exclude the year 2002 from the analysis.
} 
important in our study to control both for the direct and the moderating effect of financial constraints in order to avoid spurious correlations between our main variable of interest (i.e., the interaction between our measures of public support and appropriability) and privately financed internal R\&D expenses. So, we also include, as an additional control, the interaction between our measures of public support and financial constraints.

We control for firm size by using as a proxy the total number of employees (Size), and we enter it in logarithm in our estimations. Firm size may be correlated with R\&D effort because larger firms may obtain greater benefits from economies of scale and scope (Cohen [1995]). In addition, firm size is an alternative proxy for, and inversely related to, the existence of financial constraints.

We expect a firm's ability to undertake R\&D activities to be associated with the level of R\&D effort. First, to control for 'unobserved innovation ability,' we include in most of our estimations, firm fixed effects. Second, we also include the share of exports over total sales (Exports Intensity) and the proportion of highly skilled employees (Skilled Employment) to control for changes, over time, for such unobserved innovation ability.

Finally all specifications include year dummies; sector dummies with the two-digit CNAE code (a Spanish equivalent of the SIC classification for U.S. industries) and geographical dummies by Spanish province.

\section{EMPIRICAL ANALYSIS}

\section{IV (i). Descriptive Evidence}

Table I shows descriptive statistics for the variables described above across different categories of firms. The group of firms that received public support for $R \& D$ activities is clearly different from the group of non-supported firms. The former category demonstrates significantly higher levels of privately financed internal $R \& D$ expenses, proportion of skilled employees and propensity to export. These results are consistent with previous findings by González et al. [2005] who report that the probability of obtaining public support is positively correlated with variables reflecting research experience. Interestingly, we find that firms receiving public support report higher levels of appropriability and lower levels of financial constraints. This could suggest that public grants are not being efficiently assigned to firms for which the market failures associated with $R \& D$ activities are more severe. We do not find significant size differences in our sample between supported and non-supported firms. Turning to non-R\&D performers, as expected, they report lower levels of appropriability and higher financial constraints to undertake innovation activities. They also report a lower average propensity to export than R\&D performers, while no significant differences in size. 
TABLE I

Descriptive STATISTICS

\begin{tabular}{|c|c|c|c|c|c|c|}
\hline \multirow[b]{3}{*}{ Variable } & \multicolumn{4}{|c|}{ R\&D performers $(\mathrm{N}=5045)$} & \multicolumn{2}{|c|}{$\begin{array}{l}\text { Non-R\&D } \\
\text { performers } \\
(\mathrm{N}=2073)\end{array}$} \\
\hline & \multicolumn{2}{|c|}{$\begin{array}{l}\text { Supported firms } \\
\qquad(\mathrm{N}=1019)\end{array}$} & \multicolumn{2}{|c|}{$\begin{array}{l}\text { Non-supported } \\
\text { firms }(\mathrm{N}=4026)\end{array}$} & \multirow[b]{2}{*}{ Mean } & \multirow[b]{2}{*}{ St. Dev. } \\
\hline & Mean & St. Dev. & Mean & St. Dev. & & \\
\hline Private $R \& D$ & $1742^{* * *}$ & 7495 & 581 & 3124 & - & - \\
\hline Public Support & 342 & 1311 & - & - & - & - \\
\hline Appropriability & $0.20^{* * *}$ & 0.24 & 0.15 & 0.21 & 0.04 & 0.14 \\
\hline Financial Constraints & $0.42^{* * *}$ & 0.27 & 0.50 & 0.30 & 0.70 & 0.32 \\
\hline Size & 482 & 1458 & 448 & 3489 & 436 & 670 \\
\hline Skilled Employment & $0.07^{* * *}$ & 0.13 & 0.02 & 0.05 & - & - \\
\hline Exports Intensity & $0.32^{* * *}$ & 0.29 & 0.25 & 0.27 & 0.12 & 0.23 \\
\hline
\end{tabular}

Note: R\&D performers are firms that have made some R\&D investment in the period under analysis while NonR\&D performers are those firms that did not perform any positive internal R\&D expenditure during the whole period. Private R\&D and Public Support are in thousands of euros. The unit of observation is firm/year. We report the results of the t-test for the difference in means between supported and non-supported firms where ${ }^{* * *}$ indicates $\mathrm{p}<0.01 ;{ }^{* *}$ indicates $\mathrm{p}<0.05$ and ${ }^{*}$ indicates $\mathrm{p}<0.1$.

(a)

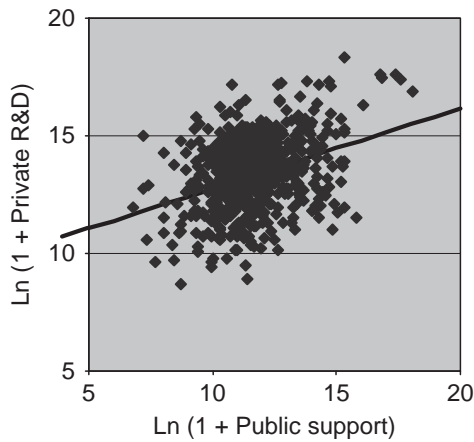

(b) Low appropriability

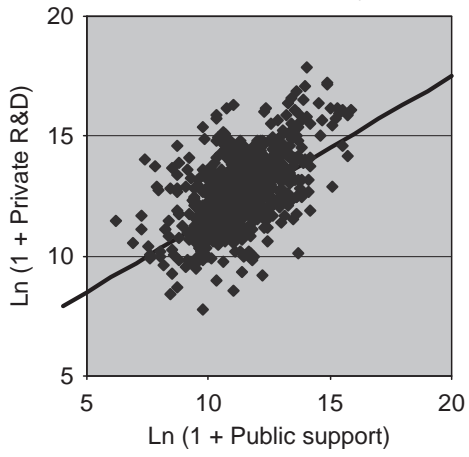

Figure 1

Public Support and Privately Financed Internal R\&D Expenses

Note: These graphs plot the logarithm of one plus public support and the logarithm of one plus privately financed internal $R \& D$ expenses for the observations with positive public support. The line corresponds to the linear prediction of the univariate regression model for each sub-sample. Exhibits (a) and (b) correspond to observations with appropriability higher and lower than the sample median respectively.

Figure I provides a first look at the relationship between public support and privately financed internal R\&D expenses, depending on the level of appropriability.

Exhibits (a) and (b) suggest that the elasticity of privately financed internal $\mathrm{R} \& \mathrm{D}$ expenses with respect to public support is positive and that there is a 
significant difference between firms according to the level of reported appropriability. For firms reporting appropriability levels lower than the sample median, the elasticity doubles that of those firms reporting higher levels of appropriability. So according to this preliminary evidence there is a positive correlation between public support and privately financed R\&D expenditures, which decreases with the level of firm appropriability.

However, as we discuss in detail below, one should be cautious about interpreting this evidence as a causal link since there may be omitted factors, correlated with either public support and privately financed internal R\&D expenses, which generate these results. The rest of the empirical analysis is devoted to exploiting the panel structure of the data in order to investigate this issue.

\section{IV (ii). Endogeneity of Public Support}

A central issue in estimating the impact of public support policies for $R \& D$ is how to deal with its potential endogeneity. The empirical evidence on R\&D support policies shows that supported and non-supported firms differ significantly, thereby indicating that public support is not randomly allocated across firms. The non-randomness of public support has two potential sources: the self-selection of firms in the participation stage and the selection criteria applied by public agencies to assign the support. Blanes and Busom [2004] provide evidence of the existence of self-selection in the participation stage for a sample of Spanish manufacturing firms. They find that larger firms and those with previous experience in $\mathrm{R} \& \mathrm{D}$ activities are more likely to participate in $R \& D$ subsidy programs. Concerning the selection criteria, although theoretically public support should be targeted to those firms that are more affected by the market failures associated with R\&D activities, in practice, public agencies have incentives to select firms that are successful at innovating ('pick up the winners') in order to prove the effectiveness of the program (Wallsten [2000]). Since the characteristics that drive both types of selection are also likely to affect the firm's R\&D investment decision, then public support may not be exogenous to privately financed internal R\&D expenditures. For instance, firms with greater innovation ability might be more likely to both apply for public support and receive it, and at the same time might have greater incentives to invest in $\mathrm{R} \& \mathrm{D}$ activities.

To reduce the possible spurious correlation between public support and privately financed internal $\mathrm{R} \& \mathrm{D}$ expenditures, we include in all of our specifications several firm level time-variant control variables. Most importantly, we include firm fixed effects that may be effective to proxy for firms' innovation ability, particularly if one thinks that innovation ability is constant over short time periods. However, even after including multiple controls, there still may be unobservable time-variant variables 
correlated with public support in the error term, which introduce a bias in the OLS estimation of the marginal effect of public support. Thus, we use instrumental variables as a means to address the remaining endogeneity of public support.

As Lichtenberg [1988] points out, an ideal instrument for the amount of public support would be the amount of funds that are potentially awardable' to the firm. We use the budget dedicated to R\&D policies, across geographical regions and sectors, as an instrument for public grants. ${ }^{12}$ We expect this variable to be correlated with the amount of public support for firms belonging to a given geographical region and sector, since the higher the potential budget the higher the likelihood of getting a grant. Also, since the budget is a policy decision, we expect it to be exogenous with respect to unobserved variables affecting a firm's $R \& D$ investment. ${ }^{13}$ In other words, we assume that, after including several control variables, the public budget for $\mathrm{R} \& \mathrm{D}$ support policies in a given sector/region is an exogenous source of variation of firm public support. Hence, the variation in this instrument results from the availability of public support and not from the access to it, thus obviating the selection problem that makes public support potentially endogenous. Given the lack of information about the public budget for $R \& D$ policies, we use the total amount for public grants by geographical region and sector, received by all firms included in the CIS survey, as a proxy for the true budget (Public Support_IV). Recall that the entire population of firms that receive some sort of public support is surveyed every year. Moreover, given the high response rate in the Spanish CIS survey $(90 \%)$ and the fact that, typically, the entire available public budget is distributed, the difference between our proxy and the real variable is likely to be very small. ${ }^{14}$

Since all specifications include two interaction terms involving public support, one with appropriability and the other with financial constraints, we instrument these two interaction terms with the product of our instrument for public support and each of the corresponding variables (appropriability and financial constraints) respectively (see Wooldridge [2002], pp.122 for a similar approach).

\footnotetext{
${ }^{12}$ Regions correspond to Comunidades Autónomas and sectors with the two digit CNAE codes.

${ }^{13}$ Hyytinen and Toivanen [2005] report that when controlling for (not) having received a subsidy, the availability of public funding (their key variable) still has a positive and significant effect on firms' R\&D investment. The potential economic explanation is that firms in regions with relatively higher availability of public funding are more likely to invest in R\&D with the expectation of receiving a subsidy. We perform a similar estimation (results available upon request) and we do not find such an 'anticipation effect' in our dataset.

${ }^{14}$ The mean value of this instrumental variable (Public support_IV) is 1064, being the minimum value 0 and the maximum one 9,650 (units in thousand of euros).
} 
Summing up, our basic estimation strategy consists of using a fixed effects transformation and then applying pooled 2SLS, where the instruments for the three endogenous variables are time demeaned (see [Wooldridge] 2002, pp. 321, for a more detailed description of this approach). Several robustness checks, all confirming our main finding, are described and reported in section V.

\section{IV (iii). Results}

Table II shows the basic results; column (1) corresponds to the OLS estimates without fixed effects, column (2) incorporates firm fixed effects and column (3) reports the instrumental variable estimation including firm fixed effects and using the instruments described above. Some comments about the specifications are necessary at this stage. First, as we take the logarithm of both privately financed internal $\mathrm{R} \& \mathrm{D}$ expenses and public support, the central coefficient of interest is interpreted as an elasticity. Second, control variables are included with one period lag in order to attenuate potential endogeneity. We thus need to drop the first period and we are left with 4,008 observations. Third, in addition to the control variables reported in the table, all estimations include year, sector and geographical dummies. ${ }^{15}$ Fourth, given that Appropriability has no time variation, we do not include it in the specifications with firm fixed effects, since it cannot be identified. In other words, the direct effect of appropriability is included in the firm fixed effect. Finally, the reported standard errors are clustered by firm for all specifications, so they are robust to heteroscedasticity and serial correlation.

We start by discussing column (3), which is the specification that tackles all endogeneity issues and yields consistent coefficients, and next we compare it with the OLS estimates (columns 1 and 2) in order to assess the effectiveness of our strategy to address the endogeneity of public support. ${ }^{16}$ The key finding emerging from column (3) is that the elasticity of privately financed internal $R \& D$ expenditures with respect to public support decreases as the level of appropriabilty increases (coefficient -0.41 , significant at $1 \%$ ).

There are a couple of plausible explanations for this finding. First, firms with stronger appropriability are more likely to ask for public support purely as a way of reducing the cost of projects that were profitable in the first place without such support; whereas those firms that face appropriability problems are more likely to ask for public support in order to make an R\&D project profitable. Second, the literature suggests that public support

\footnotetext{
${ }^{15}$ Sector and geographical dummies are included in addition to firm fixed effects because some firms (although very few) report changes in their sector classification or geographical location during the period under analysis.

${ }^{16}$ We report all specifications with both interaction terms simultaneously, but coefficients are not sensitive to their sequential inclusion.
} 
constitutes a positive signal about the quality of the $R \& D$ projects to be undertaken by the firm. This leads to an easier and cheaper access to additional funds (Lerner [1999]). This certification effect is likely to depend on the degree of appropriability. Specifically, when appropriability is weak, firms are less likely to disclose important information about their R\&D projects. In other words, the amount of information divulged, concerning $\mathrm{R} \& \mathrm{D}$ plans, is limited if intellectual property cannot be protected adequately. By contrast, when appropriability is more effective, firms can release information to the market without risking misappropriation. Thus, the endorsement perceived by the award of public support has a stronger effect for firms with weak appropriability, compared with those with effective protection mechanisms for their innovations. ${ }^{17}$

Concerning the other interaction term, we find that the elasticity of privately financed internal $R \& D$ expenditures with respect to public support is also contingent on the importance of financial constraints. Consistent with previous empirical evidence (Hyytinen and Toivanen [2005]) the stimulus effect of public support increases with the strength of the financial constraints. As mentioned above, firms with a higher degree of appropriability might have fewer problems in raising funds for their R\&D activity, suggesting a negative correlation between the importance of financial constraints and appropriability (the correlation is indeed negative and significant in our sample, $\rho=-0.12$ ). This argument highlights the importance of including the interaction between public support and financial constraints as a control in order to avoid upward bias in the estimation of the moderator effect of appropriability. ${ }^{18}$

Finally, regarding the other control variables, we find that firms facing stronger financial constraints invest less private money in internal R\&D. Also, firms with higher proportion of skilled employees and share of exports over sales invest relatively more private money in internal R\&D. This result was expected since both variables are related to a firm's innovation ability. It however vanishes when we control for firm fixed effects. Finally, firm size is

\footnotetext{
${ }^{17}$ In order to further explore this possible explanation of a 'certification effect,' we have estimated a specification using an indicator variable (i.e., a dummy) for public support instead of the logarithm of one plus the amount of public support received. Results (which are available upon request) are qualitatively unchanged and highly significant. This reveals that, independently of the size of the subsidy, firms with low appropriability invest more once they receive a grant than those firms for which appropriability mechanisms are more effective. This finding further confirms the higher value of the signaling of public grants for firms with weak appropriability. We cannot estimate a specification that includes both the dummy and the amount of public support because we do not have separate instruments, and because of the high correlation between the two.

${ }^{18}$ Since size may also proxy the importance of financial constraints, we also run a specification in which we include a third interaction term between public support and firm size as a robustness check. This interaction shows up to be insignificant. Most importantly, all other coefficients remain practically unchanged. Results are available from the authors upon request.
} 


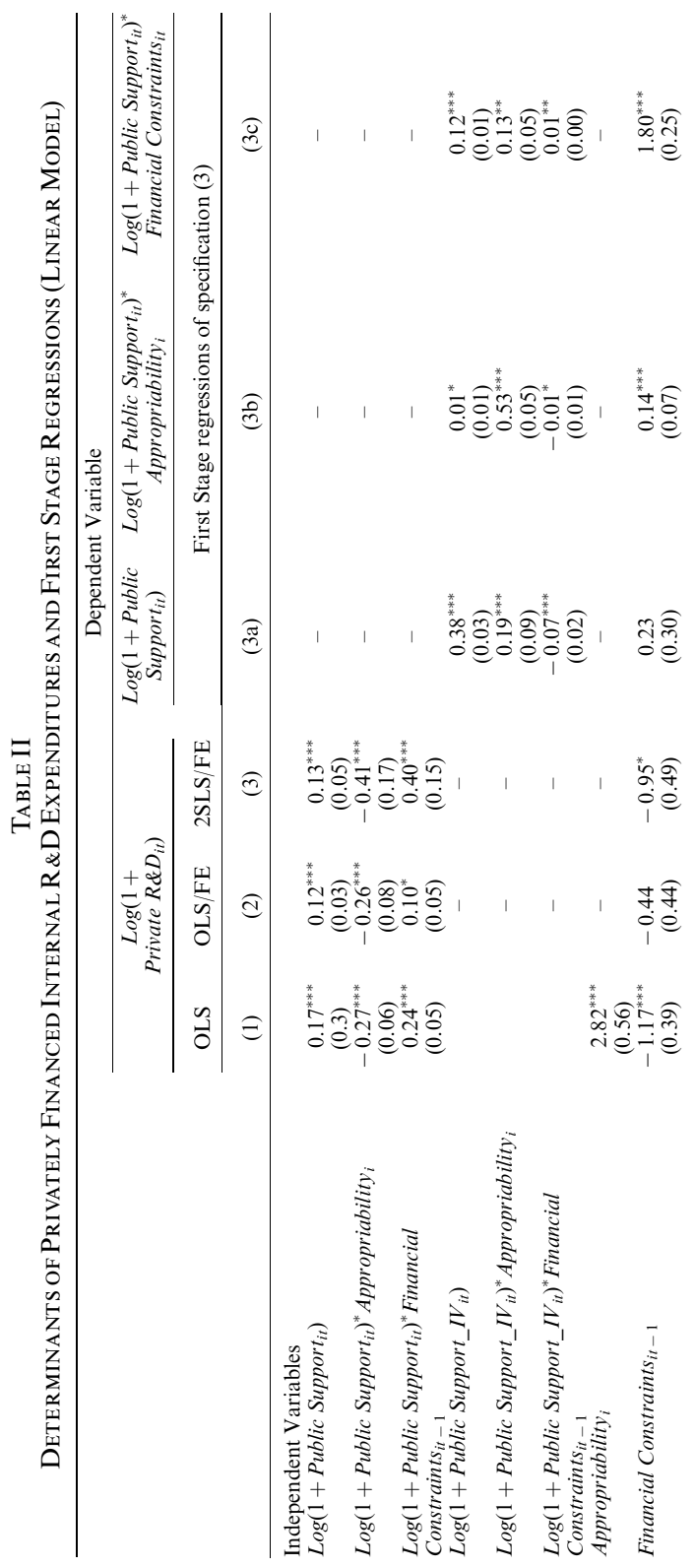




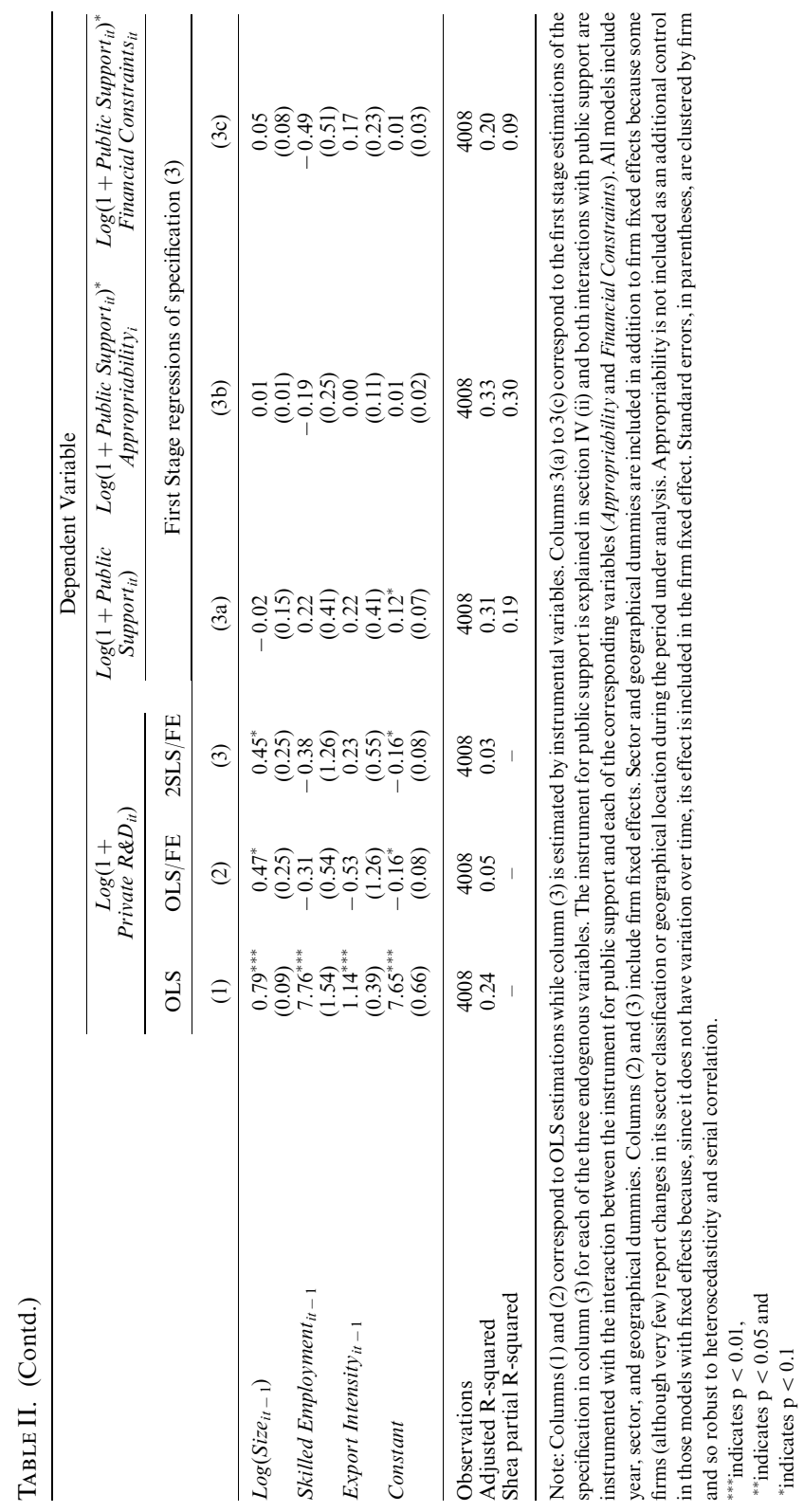


positively associated with privately financed internal $R \& D$ expenses which may be explained by economies of scale and scope in R\&D activity for bigger firms.

Concerning the validity of the instruments used, columns (3a), (3b) and (3c) show the results from the first stage estimations of the specification in column (3). There is one reduced form equation for each potentially endogenous variable. The estimated coefficients confirm that each instrument is partially correlated with the potentially endogenous variable, which is a necessary condition for the validity of the selected instrument. Since we have multiple endogenous regressors we report the partial R-squared measure proposed by Shea [1997], which takes intercorrelations among instruments into account in order to test for the sufficient relevance of the instruments to explain the endogenous regressors. Results from the Shea partial R-squared suggest that the instruments are relevant; however, the instrument for the interaction with financial constraints appears to be weaker than the other two because of its lower partial R-squared and the fact that, although significant, its partial correlation is close to zero.

To assess the effectiveness of our empirical strategy to control for the endogeneity of public support, let us compare estimates across specifications. As we discussed in the previous section, the endogeneity of public support generates a bias in the estimated coefficient of public support, which depends on the sources of the endogeneity. Usually, the empirical literature on public support for R\&D activities argues that the bias is positive, thereby implying that the unobservables are positively correlated with both receiving public support and investing private money in internal R\&D activities. Table II shows that, after incorporating firm fixed effects (i.e., moving from column (1) to column (2)), the coefficients for Public Support and for its interaction with Financial Constraints drop significantly, while the coefficient for its interaction with Appropriability remains around the same level. Overall, these changes imply that the elasticity of privately financed internal R\&D expenditures with respect to public support becomes lower. As argued above, firm fixed effects are expected to control for a firm's ability to innovate and thus they attenuate the positive bias resulting from the selfselection of the participation stage and from public agencies' incentives to 'pick up the winners' when they award support.

Finally, we compare the coefficients of the specifications in columns (2) and (3), namely, after we instrument for the endogenous variables as explained above. Notice that while the direct effect of public support remains almost unchanged, the coefficient of its interaction with Appropriability becomes more negative, thus contributing to a reduction in the overall elasticity of privately financed internal $R \& D$ expenditures with respect to public support. This goes in the direction highlighted in the related literature. However the change in the coefficient for the interaction between Public Support and Financial Constraints is positive. The increase in the 
estimated coefficient could reflect a problem of weak instruments because, although the partial correlation between the instrument and the endogenous variable is significant, its magnitude is very close to zero, as reported in column (3c).

\section{EXTENSIONS}

We ran several other specifications to verify the robustness of the significance of the interaction term between appropriability and public support estimated in column (3) of Table II. Table III reports some of them

\begin{tabular}{|c|c|c|c|}
\hline \multirow[b]{4}{*}{ Independent Variables } & \multicolumn{3}{|c|}{$\begin{array}{l}\text { TABLE III } \\
\text { S (LINEAR MODEL WITH IVAND FE) }\end{array}$} \\
\hline & \multicolumn{3}{|c|}{ Dependent Variable: $\log \left(1+\right.$ Private $\left.R \& D_{i t}\right)$} \\
\hline & \multicolumn{3}{|c|}{ 2SLS/FE } \\
\hline & (1) & (2) & (3) \\
\hline $\log _{\left(1+\text { Public support }_{i t}\right)}$ & $\begin{array}{l}0.13^{* *} \\
(0.05)\end{array}$ & $\begin{array}{l}0.13^{* *} \\
(0.06)\end{array}$ & $\begin{array}{l}0.14^{* *} \\
(0.07)\end{array}$ \\
\hline $\log (1+$ Public & $-0.42^{* *}$ & $-0.41^{* *}$ & $-0.37^{*}$ \\
\hline support $\left._{i t}\right)^{*}$ Appropriability $_{i}$ & $(0.17)$ & $(0.15)$ & $(0.20)$ \\
\hline $\log (1+$ Public & $0.40^{* * *}$ & $0.41^{* * * *}$ & $0.43^{* *}$ \\
\hline Support $\left._{i t}\right)^{*}$ Financial & $(0.15)$ & $(0.15)$ & $(0.20)$ \\
\hline $\begin{array}{l}\text { Constraints }_{i t-1} \\
\text { Financial Constraints }\end{array}$ & & & \\
\hline Financial Constraints $s_{i t-1}$ & $\begin{array}{r}-0.93^{*} \\
(0.50)\end{array}$ & $\begin{array}{r}-0.94^{*} \\
(0.50)\end{array}$ & $\begin{array}{c}-1.03^{*} \\
(0.62)\end{array}$ \\
\hline $\log \left(\right.$ Size $\left._{i t-1}\right)$ & $\begin{array}{r}0.45^{*} \\
(0.25)\end{array}$ & $\begin{array}{c}0.47^{*} \\
(0.25)\end{array}$ & $\begin{array}{l}0.55^{*} \\
(0.33)\end{array}$ \\
\hline Skilled Employment $_{i t-1}$ & $\begin{array}{r}-0.46 \\
(1.27)\end{array}$ & $\begin{array}{c}-0.20 \\
(1.27)\end{array}$ & $\begin{array}{r}-1.32 \\
(2.84)\end{array}$ \\
\hline Export Intensity $_{i t-1}$ & $\begin{array}{l}0.21 \\
(0.54)\end{array}$ & $\begin{array}{c}0.24 \\
(0.55)\end{array}$ & $\begin{array}{r}0.59 \\
(0.87)\end{array}$ \\
\hline $\begin{array}{l}\log (1+\text { External } \\
\left.R \& D_{i t-1}\right)\end{array}$ & $\begin{array}{r}0.02^{*} \\
(0.01)\end{array}$ & - & - \\
\hline $\log \left(1+\right.$ Other Funds $\left.s_{i t-1}\right)$ & - & $\begin{array}{c}-0.02 \\
(0.03)\end{array}$ & - \\
\hline Constant & $\begin{array}{r}-0.16^{*} \\
(0.08)\end{array}$ & $\begin{array}{r}-0.16^{*} \\
(0.08)\end{array}$ & $\begin{array}{c}-0.20^{*} \\
(0.10)\end{array}$ \\
\hline Observations & 4008 & 4008 & 2473 \\
\hline Adjusted R-squared & 0.03 & 0.03 & 0.04 \\
\hline
\end{tabular}

Note: All models are estimated by instrumental variables. Column (1) includes the log of one plus external R\&D investments as an additional control; column (2) includes the log of one plus other sources of funds as an additional control and column (3) restricts the estimation to those firms belonging to sectors where public contracts are hardly used. The instrument for public support is explained in section IV (ii) and both interactions with public support are instrumented with the interaction between the instrument for public support and each of the corresponding variables (Appropriability and Financial Constraints). All specifications include year, sector, geographical dummies and firm fixed effects. Firm fixed effects are included in addition to sector and geographical dummies because some firms (although very few) report changes in its sector classification or geographical location during the period under analysis. Appropriability is not included as an additional control because since it does not have variation over time its effect is included in the firm fixed effect. Standard errors, in parentheses, are clustered by firm and so robust to heteroscedasticity and serial correlation.

****indicates $\mathrm{p}<0.01$,

***indicates $\mathrm{p}<0.05$ and

*indicates $\mathrm{p}<0.1$. 
for the linear models with fixed effects, taking into account the endogeneity of public support.

Previous studies have documented the existence of complementarity between internal and external R\&D activities (e.g., Cassiman and Veugelers [2006]). Given this evidence, we may be concerned that changes in the level of external $\mathrm{R} \& \mathrm{D}$ investments (External $R \& D$ ) could affect the decision to invest in internal R\&D. We include, therefore, in column (1) of Table III, the logarithm of one plus the level of external R\&D expenditures, with one period lag, as an additional control. This variable is significant and has a positive sign suggesting the presence of some complementarity between internal and external R\&D. However, this does not affect our central result.

Another concern is related to other possible sources of support for internal $\mathrm{R} \& \mathrm{D}$ activities. The analysis is aimed at measuring the potential for public support to stimulate firms to spend additional private funds on internal R\&D activities. We consider public support as composed of funds provided by Spanish public agencies. However, there are other sources of non repayable funds for internal $\mathrm{R} \& \mathrm{D}$, like: universities, non-profit institutions, EU programs or foreign funds (Other Funds). Changes in the availability of these other sources of funds could systematically affect a firm's decision on privately financed internal $R \& D$ expenditures. In order to take into account this possible source of variation, we introduce as a control variable, with a single period lag, the logarithm of one plus the sum of these other sources of funds. Results are presented in column (2) of Table III. This new control is not significant and does not change the key findings.

We also ensure that our results are unaffected by our measure of public support, which includes both subsidies and contracts. In order to do so, we use disaggregated information about public support, provided by the surveys for the years 2003 and 2005 to find the industries where contracts are more frequent. Using this information, we compute the average level of public contracts, within each sector, and exclude those firms belonging to sectors reporting a use of contracts higher than the average level. This is the case for the following sectors: Chemical (CNAE 24), Machinery and Medical Equipment (CNAE 29), Electronic Material (CNAE 32), Other Transport Equipment (CNAE 35), Research and Development (CNAE 73) and Leisure, Culture and Sports (CNAE 92). According to our dataset, these sectors account for almost $90 \%$ of the public contracts in 2003 and 2005 . After dropping these sectors, we loose 1535 observations. Column (3) of Table III shows the results of the re-estimation with this new sample. Again, coefficients are very slightly affected and the key result of the analysis is robust.

Although not reported here, we ensure that the main result is not driven by the particular measure of appropriability. We tried other measures, taking into account not only legal but also strategic mechanisms. As argued before, a firm's R\&D decisions will be influenced by its perception of the potential to 
appropriate the returns from innovations; this potential can stem from either of the surveyed mechanisms (legal or strategic). So, we estimate our regressions with the following two alternative measures: the highest score for the seven questions regarding protection mechanisms; and the sum of the seven scores. The results are qualitatively unchanged.

Another issue we explored is to what extent this negative interaction between public support and appropriability is sustained or reverses over time (estimation available upon request). In order to analyze this issue we have estimated the specification in column (3) of Table II by adding one lag of public support and one lag of each of the interaction terms (with appropriability and financial constraints). The coefficients on the contemporaneous variables remain around the same level and highly significant as in column (3) of Table II, the lagged public support is positive and significant, while the lagged interaction term with appropriability is negative, but only significant at $12 \%$. These results suggest that there is some persistence in the effect of public support, but that the differential effect according to the level of appropriability is mostly contemporaneous.

Another possible concern is the potential bias resulting from having an unbalanced panel. Wooldridge [2002] analyzes the conditions under which fixed effect estimations are consistent with unbalanced panels. He finds that sample bias is not a problem if the selection is uncorrelated with the idiosyncratic error term of the estimated equation. In order to test this assumption, we include a lead selection indicator in the specification and test for its significance. In our panel, each firm appears in period $t$ only if it had appeared in period $t-1$. Then, for attriters our selection indicator switches from zero to one in the period just before the attrition. The selection indicator is not significant when included in the fixed effects model. So we can rule out the existence of selection bias arising from the unbalanced nature of our panel.

Finally, a more serious issue we need to deal with is the censored status of the dependent variable. Although our sample contains firms that have made some positive R\&D investment during the analyzed period, for around $20 \%$ of the firm-year observations, the value for privately financed internal R\&D is zero. So we take this into account and estimate a Tobit model. Unfortunately, when $T$ (the number of periods) is small we cannot treat firm unobserved heterogeneity as a parameter to estimate because of the 'incidental parameters problem' that produces inconsistent estimates in nonlinear models, with fixed effects (as discussed in Neyman and Scott [1948], Wooldridge [2002]). A recent work by Green [2004] shows that although the estimation bias for the slope parameters in the case of Tobit models is not severe, the estimation of the disturbance variance is downward biased and would, therefore, be transmitted to the estimates of the marginal effects. Therefore, rather than treating the unobserved effects as parameters to be estimated, we follow Chamberlain [1984] to model the distribution of 
unobserved effects conditional on the time average of the exogenous variables. This model allows the instrument to be systematically correlated with time-constant omitted factors. In addition, we take into account the potential endogeneity of public support using the same set of instruments described before. In the Appendix, following Wooldridge [2002] and Wooldridge and Papke [2007], we derive the final model to be estimated after taking into account endogeneity, time invariant unobserved heterogeneity and the censored status of the dependent variable.

In essence, to address endogeneity the estimation follows two steps, and includes the firm level average of all exogenous variables in all estimated equations to model firm fixed effects as explained above (Chamberlain [1984]). More precisely, in the first step we estimate three reduced form equations (one for each of the three endogenous variables). These equations include each corresponding instrument, the other exogenous variables and the firm level average of all exogenous variables (including the exclusion restrictions). In the second step, we estimate a pooled Tobit for privately financed internal $R \& D$ expenditures on the three endogenous variables, the exogenous control variables, the firm level average of all exogenous variables and the residuals of the first step estimations. The coefficients of the residuals provide a test for endogeneity conditional on having good instruments.

Table IV summarizes the results of the Tobit model estimated by instrumental variables and including firm fixed effects (column 1) and for its corresponding first stage estimations (columns la-1c). Table $\mathrm{V}$ reports the marginal effects of the variables of interest evaluated at the mean of the independent variables (column a), at the $5 \%$ and $95 \%$ percentiles of public support and at the mean of the other independent variables (columns b1 and b2) and some descriptive statistics of the distribution of the marginal effects across all sample observations (column c). The distribution of marginal effects across all sample observations is skewed (left skewed for Public Support and for its interaction with Financial Constraints, and right skewed for its interaction with Appropriability). However, the mean, median and mode are extremely close. In addition, the values for the $5 \%$ and $95 \%$ percentiles show that for $90 \%$ of the observations, the estimated coefficients are quite concentrated around the mean, so the marginal effects at the mean seem to be a good representation of the marginal effects for the whole sample. Interesting enough, the marginal effects at the mean are not very different from the estimated elasticities of specification (3) of Table II, further confirming the robustness of the findings. ${ }^{19}$

\footnotetext{
${ }^{19}$ The results are also qualitatively unchanged if we use the unrestricted sample instead of focusing on the analysis of the sample of firms that perform some R\&D during the period under analysis. In the unrestricted sample internal R\&D expenses is uncensored for 3,203 observations and censored for the remaining 2,418 .
} 
From the estimated elasticities, we can compute the derivative of privately financed internal $\mathrm{R} \& \mathrm{D}$ expenses with respect to public support. Using the average level of public support, appropriability and financial constraints for the whole sample, the derivative is 1.25 . If we divide the sample according to the level of appropriability, then for those firms reporting appropriability lower than the median, the derivative is around 1.75, while for those firms reporting appropriability higher than the median it is around 0.60 (almost three times smaller). Given that the maximum support provided generally to private firms by the major support programs in Spain accounts for at most $50 \%$ of the project ${ }^{20}$, and that the dependent variable of this analysis corresponds to internal funds invested in R\&D (so it does not include the public support), the derivatives we compute above evidence a strong stimulus for the group of firms with the lowest levels of appropriability. With regard to the group of firms with higher appropriability, the average marginal effect reflects a much weaker stimulus. Moreover, we find that, at the average values of all other independent variables, for firms with appropriability higher than 0.65 (which are almost $7 \%$ of the supported firms), we cannot rule out the existence of some crowding-out effect. This evidence is however weak. In fact, a t-test on the hypothesis that the effect of public support is not different from zero for the highest level of appropriability, (i.e., 1), and evaluating financial constraints at the median, does not allow us to reject the null hypothesis in all specifications. We can, however, reject such null hypothesis for specification (3) of Table II when financial constraints are set at the lowest value. ${ }^{21}$

Finally, concerning the validity of the instruments used, columns (1a) to (1c) in Table IV show the results from the first stage estimations of the specification in column (1). There is one reduced form equation for each potentially endogenous variable. The estimated coefficients confirm that each instrument is partially correlated with the potentially endogenous variable, which is a necessary condition for the validity of the selected instrument. In addition, given the reported $\mathrm{F}$ statistic, we reject that the sum of the reduced form residuals equals zero justifying the use of instrumental variables. ${ }^{22}$

\footnotetext{
${ }^{20}$ This is the case for programs from the Ministry of Science and Education (PROFIT Program), Ministry of Transportation and Public Investments (through the Centre for Experimentation for Public Investments-CEDEX), Ministry of Industry Tourism and Commerce (CENIT and PROFIT Programs), Madrid Local Government (through the IMADE and FEDER Programs) and the Ministry of the Environment, among others.

${ }^{21}$ However, given that the maximum support provided generally to private firms by the major support programs in Spain accounts for at most $50 \%$ of the project, the fact that overall privately financed $\mathrm{R} \& \mathrm{D}$ remains flat might imply that some crowding out occurs at nonsupported $\mathrm{R} \& \mathrm{D}$ projects.

${ }^{22}$ Notice that when the sum of the reduced form residuals is different from zero, the standard errors of the second stage are not asymptotically valid. Since this is the case in column (1) we have re-estimated the model by MLE (which provides correct standard errors). Our central coefficients remain statistically significant (see Wooldridge [2002], pp.532).
} 
V (i). A Matching Approach

As an additional robustness check, we use a matching approach to estimate the counterfactual of the treated observations of our sample of performing firms. We apply the bias corrected nearest-neighbour matching estimator proposed by Abadie and Imbens [2006] and follow González and Pazó

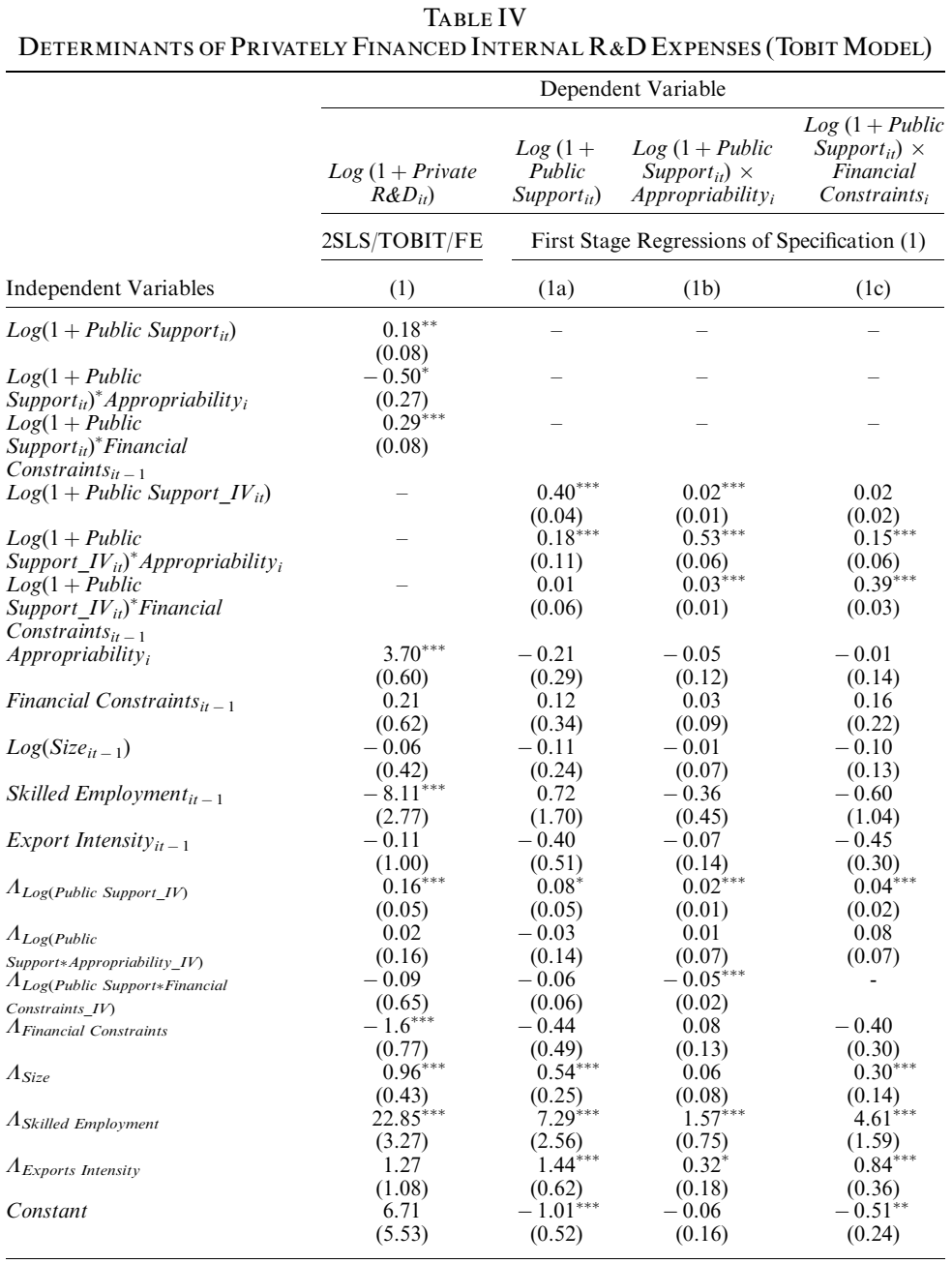




\begin{tabular}{|c|c|c|c|c|}
\hline \multirow[b]{4}{*}{ Independent Variables } & \multicolumn{4}{|c|}{ Dependent Variable } \\
\hline & $\begin{array}{c}\log (1+\text { Private } \\
\left.R \& D_{i t}\right) \\
\end{array}$ & $\begin{array}{c}\log (1+ \\
\text { Public } \\
\left.\text { Support }_{i t}\right) \\
\end{array}$ & $\begin{array}{c}\log (1+\text { Public } \\
\left.\text { Support }_{\text {it }}\right) \times \\
\text { Appropriability }_{i}\end{array}$ & $\begin{array}{c}\text { Log }(1+\text { Public } \\
\left.\text { Support }_{\text {it }}\right) \times \\
\text { Financial } \\
\text { Constraints }_{i} \\
\end{array}$ \\
\hline & 2SLS/TOBIT/FE & \multicolumn{3}{|c|}{ First Stage Regressions of Specification (1) } \\
\hline & (1) & (1a) & (1b) & (1c) \\
\hline$F(p, q)$ & $2.89^{*}(1,3894)$ & - & - & - \\
\hline Uncensored obs. & 3203 & 4008 & 4008 & 4008 \\
\hline Censored obs. & 805 & & & \\
\hline Chi2 (DF) & $1140^{* * *}(113)$ & - & - & - \\
\hline Adjusted R-squared & - & 0.47 & 0.43 & 0.44 \\
\hline
\end{tabular}

Note: the specification in column (1) is a Tobit model with firm fixed effects estimated by instrumental variables as described in the text. The instrument for public support is explained in section IV (ii) and both interactions with public support are instrumented with the interaction between the instrument for public support and each of the corresponding variables (Appropriability and Financial Constraints). The terms ' $\Lambda_{\text {Variable' }}$ refer to the firmlevel mean of the corresponding variable. These terms are included in the specifications to model firm fixed effects as explained in section V. The errors of the first stage estimations are included in specification of column (1); we report the F statistic of testing the null hypothesis that the sum of the reduced form residuals equals zero. Columns (1a)-(1c) correspond to the first stage estimations of specification in column (1). All specifications include year, industry and geographical dummies. Standard errors, in parentheses, are clustered by firm so robust to heteroscedasticity and autocorrelation.

${ }^{* * * *}$ indicates $\mathrm{p}<0.01$

***indicates $\mathrm{p}<0.05$ and

*indicates $\mathrm{p}<0.1$.

TABLEV

Marginal Effects of Model (I) inTable IV for Central Regressors

\begin{tabular}{|c|c|c|c|c|c|c|c|c|c|c|}
\hline & \multirow{2}{*}{$\begin{array}{c}\begin{array}{c}\text { Marginal } \\
\text { effects }\end{array} \\
\text { (a) }\end{array}$} & \multicolumn{2}{|c|}{$\begin{array}{l}\text { Marginal } \\
\text { effects }\end{array}$} & \multicolumn{7}{|c|}{ Marginal effects } \\
\hline & & (b1) & (b2) & & & & (c) & & & \\
\hline & & & & Mean & Median & Mode & $\mathrm{Sd}$ & Sk. & $\begin{array}{l}5^{\text {th }} \\
\%\end{array}$ & $\begin{array}{l}95^{\text {th }} \\
\%\end{array}$ \\
\hline $\begin{array}{l}\log (1+\text { Public } \\
\left.\text { Support }_{i t}\right)\end{array}$ & 0.17 & 0.17 & 0.18 & 0.17 & 0.17 & 0.17 & 0.015 & -2.58 & 0.14 & 0.18 \\
\hline $\begin{array}{l}\log (1+\text { Public } \\
\left.\text { Support }_{i t}\right)^{*}\end{array}$ & -0.47 & -0.46 & -0.49 & -0.47 & -0.48 & -0.49 & 0.041 & 2.60 & -0.50 & -0.39 \\
\hline $\begin{array}{l}\text { Appropriability }_{i} \\
{\text { Log }(1+\text { Public }}_{\left.\text {Support }_{\text {it }}\right)^{*} \text { Financial }} \\
\text { Constraints }_{\text {it }-1}\end{array}$ & 0.27 & 0.27 & 0.28 & 0.27 & 0.28 & 0.27 & 0.024 & -2.59 & 0.23 & 0.29 \\
\hline
\end{tabular}

Note: marginal effects (a) correspond to the marginal effects evaluated at the mean values of the independent variables. Marginal effects (b1) and (b2) correspond to the marginal effects evaluated at percentile $5 \%$ and $95 \%$ of public support respectively and at the mean values of the other independent variables. Marginal effects (c) report some descriptive statistics of the marginal effects across the sample.

[2008] for its implementation in order to make our results comparable to another study that uses Spanish data (although they employ a different sample and a different time window). Notice that while in the specifications 
estimated until now, the treatment is continuous (since it is the amount of public support), the matching estimator we propose here tests the effect of a binary treatment that indicates whether the firm received public support or not. Nevertheless, if the results are consistent, it does constitute an additional piece of support for the central hypothesis of this paper.

Critical to the application of matching estimators is the selection of the set of characteristics that will determine the construction of the control sample. The first variable used is the propensity score, which is the estimated probability of receiving public support. In order to generate the propensity score, we estimate a probit model where the dependent variable takes the value one if the firm receives public support and zero otherwise. The independent variables included in the estimation are the following: first, a dummy variable reporting if the firm received public support in the previous period to capture persistence in the assignment of public support; second, firm level characteristics like size, export propensity, proportion of skilled workers, appropriability and financial constraints (see section III (iii) for a description of all these variables). Third, we include a dummy variable that takes the value one if more than fifty percent of the firm is owned by foreign capital (Foreign Ownership) to proxy the level of internationalization of the firm, which may also influence the agency decision to award public support. Finally, we include year, sector and geographical dummies.

The results of the estimated specification are presented in Table VI. The percentage of correctly predicted outcomes denotes a reasonable goodness

TABLEVI

Probability Equation for Public Support

\begin{tabular}{|c|c|}
\hline Independent Variables & Dependent Variable: Indicator of Public Support at time $t$ \\
\hline Indicator of Public Support at time $e_{t-1}$ & $\begin{array}{l}0.42^{* * *} \\
(0.02)\end{array}$ \\
\hline Appropriability $_{i}$ & $\begin{array}{c}0.01 \\
(0.03)\end{array}$ \\
\hline Financial Constraints $_{i t-1}$ & $\begin{array}{l}-0.08^{* * *} \\
(0.02)\end{array}$ \\
\hline $\log \left(\right.$ Size $\left._{i t-1}\right)$ & $\begin{array}{l}0.04^{* * * *} \\
(0.01)\end{array}$ \\
\hline Skilled Employment ${ }_{i t-1}$ & $\begin{array}{l}0.36^{* * *} \\
(0.13)\end{array}$ \\
\hline Exports Intensity $_{i t-1}$ & $\begin{array}{l}0.10^{* * *} \\
(0.02)\end{array}$ \\
\hline Foreign Ownership $_{i t-1}$ & $\begin{array}{c}-0.05^{* * *} \\
(0.01)\end{array}$ \\
\hline Observations & 3537 \\
\hline Correctly predicted observations & 0.85 \\
\hline
\end{tabular}

Note: The reported coefficients correspond to the marginal effects of the probit model for the probability of obtaining public support. The dependent variable takes the value 1 if the firm received public support in year $t$ and zero otherwise. The estimated model includes year, sector and geographical dummies. The percentage of correctly predicted observations is a weighted average of the percentage of correctly predicted zeros and ones weighted by the fractions of zero and one outcomes. Standard errors are reported in parentheses and ${ }^{* * *}$ indicates $\mathrm{p}<0.01,{ }^{* *}$ indicates $\mathrm{p}<0.05$ and ${ }^{*}$ indicates $\mathrm{p}<0.1$. 
of fit. The sign and significance of the estimated coefficients is consistent with previous empirical results for Spain (González and Pazó [2008], González et al. [2005] and Busom [2000]), which indicate that there is significant persistence in public support and that firms awarded public support for $\mathrm{R} \& \mathrm{D}$ activities are typically bigger, have greater research experience, are more internationalized, but are mostly financed by national capital. Concerning appropriability, although the coefficient is not significant when we include the lagged indicator variable for public support, it becomes highly significant when we exclude this variable.

Using the estimated parameters of the probit model we obtain predictions of the probability of getting public support for all sample firms (propensity score) that we later use as one of the matching criteria. The other covariates used to construct the control sample are the lagged level of privately financed internal $R \& D$ expenditures to capture persistence in $R \& D$ activities, the lagged public support dummy to capture persistence of public support and finally size, sector and time dummies. ${ }^{23}$

Table VII provides the mean values of the subsamples of supported, nonsupported firms and the control group obtained after the matching, for the whole sample and for the two subgroups with higher and lower level of appropriability respectively (above and below the median value, respectively). We report the tests comparing the mean of the treated firms with each of the other two groups. While supported and non-supported firms appear very different before the matching, clearly the differences have been reduced significantly after the matching.

Finally, Table VIII reports the estimated SATT (Sample Average Treatment Effect on the Treated) on privately financed internal R\&D expenses for the whole sample of R\&D performing firms and for the two subgroups with higher and lower level of appropriability. We find that while those firms with appropriability lower than the median invest significantly more when they receive public support, the effect of receiving public support is not significantly different from zero for firms with appropriability higher than the median. These results are consistent with our contention that the propensity to devote private expenses to $R \& D$ after receiving public support is larger for firms that report low appropriability.

Overall, the results of the several robustness checks summarized in this section support the view that the effect of public support on privately financed internal $\mathrm{R} \& \mathrm{D}$ expenses is heterogeneous across firms, and that the level of appropriability explains part of these differences.

${ }^{23}$ Following González and Pazó [2008], we consider two size brackets (less and more than 200 workers) and aggregate manufacturing sectors in accordance with the standard industrial aggregation of the Spanish National Institute of Statistics (INE); we also aggregate services in a single category. 


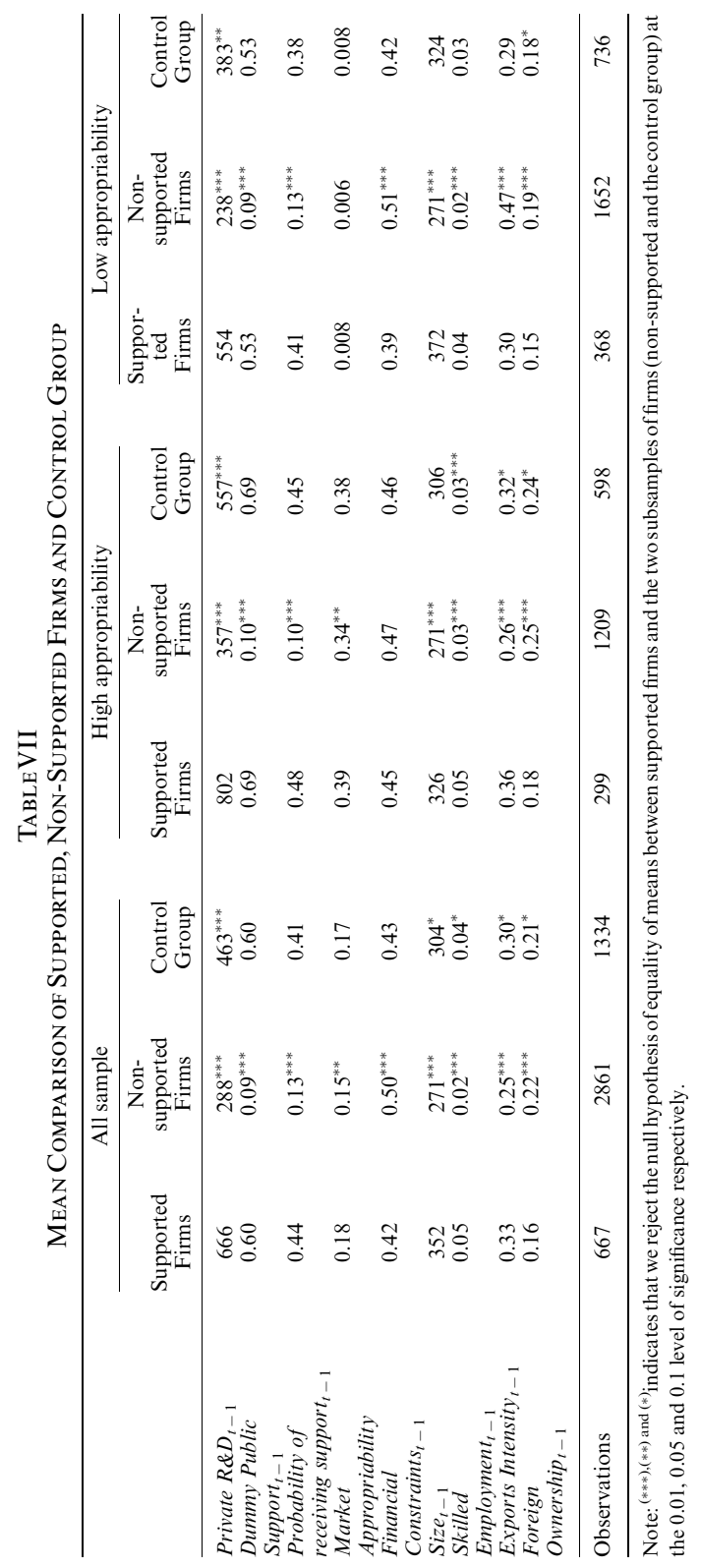


TABLEVIII

Average Treatment EfFect for The Supported Firms

\begin{tabular}{lccc}
\hline & All the sample & High Appropriability & Low Appropriability \\
\cline { 2 - 4 } & 53413 & 38809 & $197614^{* *}$ \\
Private $R \& D$ & $(75780)$ & $(82336)$ & $(97431)$ \\
\hline Observations & 3528 & 1508 & 2020 \\
Treated Group & 667 & 299 & 368 \\
Control Group & 1334 & 598 & 736 \\
\hline
\end{tabular}

Note: Standard errors in parentheses are robust to heteroescedasticity. ${ }^{* * *}$ indicates $\mathrm{p}<0.01$,

${ }^{* *}$ indicates $\mathrm{p}<0.05$ and $^{*}$ indicates $\mathrm{p}<0.1$

\section{CONCLUSIONS}

This paper uses data from the Community Innovation Survey (CIS) for the period 2000-2005 carried out in Spain by the National Institute of Statistics (INE) to investigate the interaction between public support for $R \& D$ activities and appropriability. Taking into account the potential endogeneity of public support, firm unobserved heterogeneity, several other controls, among which the strength of financial constraints, and after running a variety of robustness tests, we find evidence of a significant negative interaction between public support and appropriability. More precisely, the estimated elasticities correspond to a derivative of 0.60 for firms reporting higher levels of appropriability (i.e., above the median level), while the derivative reaches 1.75 for those firms for which appropriability mechanisms are weaker (i.e., below the median level). On average, the stimulation effect is therefore three times larger for the half of the sample for which the appropriability market failure is more severe. In addition to the support of the existence of a negative moderating effect of appropriability, the estimated coefficients also suggest the possibility of some extent of crowding out among those firms reporting the highest levels of appropriability.

This paper makes therefore a contribution to the empirical literature on public support for R\&D activities by demonstrating that the effect of public support is heterogeneous across firms, and that the level of appropriability is crucial in explaining those differences. Too often the literature has treated firms receiving public support as homogeneous, focusing mainly on the estimation of the average affect of public support on the level of privately financed R\&D expenses. There are some exceptions: Hyytinen and Toivanen [2005] have provided empirical evidence on the relevance of financial constraints as a contingency factor in the effect of public support. González and Pazó [2008], González et al. [2005], Lach [2002] investigate firm size as a source of heterogeneity (firm size is expected to be negatively related to the access to capital markets). They show that small firms are more reactive to public support than bigger firms are.

This paper is not the first one using Spanish data to analyze the effect of public support for R\&D activities. A couple of recent papers (González and 
Pazó, [2008], González et al. [2005]) use a panel data from the Survey of Firm Strategies (Encuesta de Estrategias Empresariales) between 1990 and 1999 to assess the effectiveness of public support. However, although these papers discuss the role of firm size, their focus is more about measuring the average effect of public support and the possible existence of crowding out. Instead, we are more concerned about explaining the hetoregeneity across firms due to the degree of appropriability. To this end, we exploit information provided exclusively by the CIS survey on the effectiveness of appropriability mechanisms and on the strength of financial constraints to build firm level measures with the purpose of decomposing the average effect of public support along these two dimensions. Despite the different focus of our paper, and the fact that we use another database and time window, our results are consistent with previous findings for Spanish firms. First, we find that public support goes mainly to firms with some level of R\&D experience. Second, our finding that financial constraints as well as the degree of appropriability play a central role in explaining differences between firms is in accordance to the finding that smaller firms are stimulated more by public support. This is so because small firms are expected to face more financial constraints and have therefore less developed mechanisms for appropriating the returns of their R\&D activity than large firms do. Finally, concerning the magnitude of the average effect of public support on privately financed $R \& D$ expenses, we find a stronger effect for our period of study.

Overall, our findings suggest that when appropriability is weak, crowding out is much less likely than when protection mechanisms are strong and effective. So, government agencies should be particularly careful when allocating funds to firms with strong appropriability. A related implication is that innovation policies that are aimed at increasing appropriability, for instance by tightening up IPR issues, cannot be treated separately from policies aimed at increasing public support. Indeed, our findings show indirectly that ignoring this interaction can give rise to an important misallocation of public money.

\section{APPENDIX \\ TOBIT MODEL FOR PANEL DATA WITH AN ENDOGENOUS REGRESSOR}

In this technical appendix we describe how to estimate a Tobit model for panel data with a large cross-sectional dimension and relatively few time periods allowing for timeconstant unobserved effects that can be correlated with the explanatory variables and for the presence of an endogenous variable.

Assume we have the following model,

$$
\begin{aligned}
& y_{i t 1}=\max \left(0, z_{i t 1} \delta_{1}+\alpha_{1} y_{i t 2}+c_{i 1}+u_{i t 1}\right) \\
& y_{i t 2}=z_{i t} \delta_{2}+c_{i 2}+u_{i t 2} \\
& \left(u_{i t 1}, u_{i t 2}\right) \mid z_{i}, c_{i 1}, c_{i 2} \sim \text { bivariate normal }
\end{aligned}
$$


Where $c_{i 1}$ is a time invariant unobserved effect, $z_{i t}=\left(z_{i t 1} . z_{i t 2}\right)$ are exogenous variables with one exclusion restriction and $u_{i t 1}$ represent time varying omitted factors that can be correlated with $y_{i t 2}$. For simplicity we assume only one endogenous variable, but the extension for more than one is straightforward provided there are sufficient instruments.

Following Chamberlain [1984] we make the following assumptions to model the heterogeneity:

$$
\begin{aligned}
& c_{i 1}=\psi_{1}+\bar{Z}_{i} \zeta_{1}+a_{i 1} \\
& c_{i 2}=\psi_{2}+\bar{Z}_{i} \zeta_{2}+a_{i 2}
\end{aligned}
$$

with $\left(a_{i 1}, a_{i 2}\right)$ independent of $z_{i}$ and where $\bar{Z}_{i}=T^{-1} \sum_{t=1}^{T} z_{i t}$ is the vector of time averages for each exogenous variable (including those omitted from (1)). Plugging (3) and (4) respectively into (1) and (2) we have

$$
\begin{aligned}
& y_{i t 1}=\max \left(0, z_{i t 1} \delta_{1}+\alpha_{1} y_{i t 2}+\psi_{1}+\bar{Z}_{i} \zeta_{1}+a_{i 1}+u_{i t 1}\right) \\
& y_{i t 2}=\psi_{2}+z_{i t} \delta_{2}+\bar{Z}_{i} \zeta_{2}+a_{i 2}+u_{i t 2}
\end{aligned}
$$

and under joint normality,

$$
v_{i t 1}=\rho_{1} v_{i t 2}+e_{i t 1}, e_{i t 1} \mid\left(z_{i}, v_{i t 2}\right) \sim \operatorname{Normal}\left(0, \sigma_{e 1}^{2}\right), t=1, \ldots, T .
$$

Where $v_{i t 1}=a_{i 1}+u_{i t 1}$ and $v_{i t 2}=a_{i 2}+u_{i t 2}$ So finally we can write,

$$
y_{i t 1}=\max \left(0, \psi_{1}+z_{i t 1} \delta_{1}+\bar{Z}_{i} \zeta_{1}+\alpha_{1} y_{i t 2}+\rho_{1} v_{i t 2}+e_{i t 1}\right)
$$

Because $e_{i t 1}$ is independent of $\left(z_{i}, v_{i t 2}\right)$ it is also independent of $y_{i t 2}$. Now $y_{i t 2}$ is contemporaneously exogenous in (7) but not necessarily strictly exogenous so we proceed to estimate in the following two stages. First we estimate pooled OLS of $y_{i t 2}$ on $1, z_{i t}, \bar{Z}_{i}$ and get the residuals $\hat{v}_{i t 2}$. The next step is to estimate pooled Tobit of $y_{i t 1}$ on 1 , $z_{i t 1} . \bar{Z}_{i}, y_{i t 2}, \hat{v}_{i t 2}$ obtaining $\hat{\delta}_{1}, \hat{\alpha}_{1}, \hat{\psi}_{1}, \hat{\xi}_{1}, \hat{\rho}_{1}$ and $\hat{\delta}_{e 1}^{2}$. Finally we compute marginal effects.

\section{REFERENCES}

Abadie, A. and Imbens, G. W., 2006, 'Large Sample Properties of Matching Estimators for Average Treatment Effects,' Econometrica, 74(1), pp. 235-267.

Arrow, K., 1962, 'Econometric Welfare and the Allocation of Resources to Invention,' in Nelson., R. ed. The Rate and Direction of Inventive Activity (Princeton University Press, Princeton, New Jersey, U.S.A.).

Blanes, J. V. and Busom, I., 2004, 'Who Participates in R\&D Subsidy Programs? The Case of Spanish Manufacturing Firms,' Research Policy, 33, pp. 1459-1476.

Busom, I., 2000, 'An Empirical Evaluation of the Effects of R\&D Subsidies,' Economics of Innovation and New Technology, 9, pp. 111-148.

Cassiman, B. and Veugelers, R., 2002, 'R\&D Cooperation and Spillovers: Some Empirical Evidence from Belgium,' The American Economic Review, 92, pp. 1169 1184.

Cassiman, B. and Veugelers, R., 2006, 'In Search for Complementarity in Innovation Strategy: Internal R\&D and External Knowledge Acquisition,' Management Science, 52 , pp. $68-82$. 
Chamberlain, G., 1984, 'Panel Data,' in Griliches, Z. and Intrilligator, M., eds., Handbook of Econometrics (Elsevier, North Holland, Amsterdam, The Netherlands). Cockburn, I. and Griliches, Z., 1988, 'Industry Effects and Appropriability Measures in the Stocks Market Valuation of R\&D and Patents,' American Economic Review, 78, pp. 419-423.

Cohen, W., 1995, 'Empirical Studies of Innovative Activity,' in Stoneman, N., ed., Handbook of the Economics of Innovation and Technology (Elsevier, North Holland, Amsterdam, The Netherlands).

Czarnitzki, D. and Licht, G., 2006, 'Additionality of Public R\&D Grants in a Transition Economy: the Case of Eastern Germany,' Economics of Transition, 14, pp. 101-131.

David, P. A.; Hall, B. H. and Toole, A. A., 2000, 'Is Public R\&D a Complement or Substitute for Private R\&D? A Review of the Econometric Evidence,' Research Policy, 29, pp. 499-532.

González, X.; Jaumandreu, J. and Pazó, C., 2005, 'Barriers to Innovation and Subsidy Effectiveness,' The Rand Journal of Economics, 36, pp. 930-950.

González, X. and Pazó, C., 2008, 'Do Subsidies Stimulate Private R\&D Spending?,' Research Policy, 37(3), pp. 371-389.

Green, W., 2004, 'Fixed Effects and Bias Due to the Incidental Parameters Problem in the Tobit Model,' Econometric Reviews, 23-2, pp. 125-147.

Griliches, Z., 1992, 'The Search of R\&D Spillovers,' Scandinavian Journal of Economics, 94 , pp. $29-47$.

Hall, B., 2002, 'The Financing of Research and Development,' Oxford Review of Economic Policy, 18, pp. 35-51.

Hall, B. and Van Reenen, J., 2000, 'How Effective are Fiscal Incentives for R\&D? A Review of the Evidence,' Research Policy, 29, pp. 449-469.

Hyytinen, A. and Toivanen, O., 2005, 'Do Financial Constraints Hold Back Innovation and Growth?,' Evidence on the Role of Public Policy. Research Policy, 34, pp. 1385-1403.

Jaffe, A. B., 1996, Economic Analysis of Research Spillovers: Implications of the Advanced Technology Program (Washington D.C.: U.S. Department of Commerce, National Institute of Standards and Technology, Advanced Technology Program).

Klette, J.; Moen, J. and Griliches, Z., 2000, 'Do Subsidies to Commercial R\&D Reduce Market Failures? Microeconometric Evaluation Studies,' Research Policy, 29, pp. 471495.

Lach, S., 2002, 'Do R\&D Subsidies Stimulate or Displace Private R\&D? Evidence from Israel,' Journal of Industrial Economics, 4, pp. 369-390.

Lerner, J., 1999, 'The Government as Venture Capitalist: The Long-Run Impact of the SBIR Program,' The Journal of Business, 72, pp. 285-318.

Levin, R. C.; Klevoric, A. K.; Nelson, R. R. and Winter, S. G., 1987, 'Appropriating the Returns from Industrial Research and Development,' Brookings Papers in Economic Activity, 3, pp. 783-820.

Lichtenberg, F., 1988, 'The Private R\&D Investment Response to Federal Design and Technical Competition,' The American Economic Review, 78, pp. 550-559.

Nelson, R. R., 1959, 'The Simple Economics of Basic Scientific Research,' Journal of Political Economy, 67, pp. 297-306.

Neyman, J. and Scott, E., 1948, 'Consistent Estimates Based on Partially Consistent Observations,' Econometrica, 16, pp. 1-32.

Shea, J., 1997, 'Instrument Relavance in Multivariate Linear Models: A Simple Measure,' Review of Economics \& Statistics, 79(2), pp. 348-352.

Teece, D., 1986, 'Profiting from Technological Innovation,' Research Policy, 15, pp. 285-305. Wallsten, J., 2000, 'The Effect of Government Industry R\&D Programs on Private R\&D: the Case of the Small Business Innovation Research Program,' Rand Journal of Economics, 31, pp. 82-100. 
Wooldridge, J. M., 2002, Econometric Analysis of Cross Section and Panel Data (MIT Press, Cambridge, Massachusetts, U.S.A.).

Wooldridge, J. M. and Papke, L., 2007, 'Panel Data Methods for Fractional Response Variables with an Application to Test Pass Rates,' (working paper, Department of Economics, Michigan State University, Laursing, Michigan, U.S.A.). 